\title{
Study on Construction of Top-ranking Foreign Language Profession under the Guidance of Ideology and Politics
}

Qiongfang Qin

School of Foreign Languages, Guilin Tourism University, Guilin 541006, Guangxi Province, China

\begin{abstract}
As college students are the main force in the building of our country, we should highlight every profession for college students, and enhance the teaching effect of every class. That said, it will make direct impact on the morality of society in the new era. With the more prominent tendency of economic globalization and the rapid development of Internet, the culture of our country has been effected by the Western culture to some extent. Faced with this tendency, the Ministry of Education in our country has put forward the new requirement for the construction of "double world class". Foreign language study is one of the core lectures in the Technician Training School. We should adhere to the role of guidance of ideology and politics and speed up the building process of top-class profession. That is how we can upgrade the teaching of foreign language in college.
\end{abstract}

Keywords: Guidance of ideology and politics; Subject of foreign languages; Construction of world class profession

Publication date: December, 2020

Publication online: 31 December, 2020

"Corresponding author: Qiongfang Qin, 8350 34730@qq.com

In 2016, President Xi Jinping mentioned that ideology and politics should be run through the entire process of teaching to achieve comprehensive education. Report of the 19th National Congress of the Chinese Communist Party emphasized the importance of education again, and regarded it as a basic project for the great rejuvenation of the Chinese nation. The development of education is prioritized decidedly, and educators must truly implement the Communist party's educational policy in actual teaching to complete the fundamental task of fostering virtue through education. Foreign language is one of the basic subjects in universities and plays a vital role in the future international exchange of students. As Western culture continues to penetrate into our country, the author believes that it is necessary to integrate ideology and politics in the process of profession construction of foreign languages and insist on the leading of ideology and politics. The author will analyze this below to provide ideas for the construction of world-class majors in foreign language disciplines in universities.

1 The necessity for the construction of topclass majors in foreign language disciplines under the guidance of ideology and politics

The ultimate goal of first-class professional construction is to cultivate great talents who meet the requirements of the country. The training of innovative talents is related to the improvement of teachers' literacy and the construction of foreign language courses. Comrade Xi Jinping once emphasized the importance of cultivating virtue of people and being a teacher as a norm at a forum on ideological and political work in our country. The prerequisite for teachers to cultivate students is to understand and believe the role of teacher. College teachers should highlight the cultivation of their own morality, teach the students by virtue, and strive to be the disseminators of ideology and culture in the new era. In addition, we should persist in the unwavering leadership of the Communist party and take on the important task of leading students on the path of healthy growth. In the process of teaching the 
students the truth, the teacher's words and deeds also set an example for the students, which can variously change the students' thinking mode with a huge impact. Therefore, the author holds that teachers need to continuously enhance their political awareness, improve their understanding of literacy to broaden their horizons. And they should further upgrade teaching methods, and cultivate a sense of social responsibility from students who can actually become talents once they grow up. That is how we can insist the leading role of ideology and politics and construct the world-class foreign language profession.

\section{The status quo of the construction of first- class majors in foreign languages}

First, the college administration focus its work on the acquisition of professional knowledge and the training of professional ability, but lacks sufficient attention to its responsibilities and role in cultivating virtue of students. For example, most schools measure the teaching level of teachers mainly through the grade of students. Some colleges and universities also equates English test certificates with diploma. Students didn't learn English out of interest, but only because they have to obtain a diploma. Under these circumstances, students don't have a correct understanding of learning English, which is negative to the improvement of students' English ability. It is also the same for learning other foreign languages. Knowledge of the language is highly emphasized, while ignoring the moral education. That is because students who learn other foreign languages are beginners.

Second, the teachers' teaching concepts are backward and lack the correct understanding of ideological and political education. Taking French as an example, French teachers teach language knowledge through French courses, and further cultivate students' spontaneous learning ability, crosscultural communication skills and improve students' personal qualities. However, French teachers have biased understanding of the teaching objectives of French subjects. They believe that the main purpose of French teaching is to impart knowledge and language skills of French and moral education has nothing to do with French subject and instead it shall be undertaken by ideological and political courses. This backward educational concept no longer adapts to the teaching concept of "three-dimensional education" in Chinese colleges and universities. The traditional concept of teaching French in our country has been neglecting the cultivation of students' ideological and political concepts, moral character, and social skills. The core goal of French teaching and the educational responsibility of French are overlooked.

Third, the edition of textbooks and the selection of content are short of ideological and political education. As the carrier of foreign language teaching class, foreign language textbooks embody the teaching philosophy, teaching content and teaching goals of teachers. The teaching materials not only convey language knowledge, but also reflect the social value and ethics. The integration of ideological and political education in foreign language teaching mainly relies on teachers' in-depth exploration of the content of foreign language textbooks, searching for the ideological and political education elements contained in the textbooks, and infiltrating these ideological and political education elements into the professional curriculum teaching, and exerting a quiet and silent effect. Influence the role and guide students to gradually establish correct personal beliefs and moral concepts. In the foreign language textbooks of colleges and universities, the compilation of some textbooks well reflects the function of ideological and political education, and political education is further incorporated in the selection of textbook content. However, there are still some English textbooks with empty content, focusing only on the application of foreign language knowledge, introduction of foreign geography and culture, lack of comparison with traditional Chinese culture. The textbooks didn't use Western cultural concepts to analyze the customs of our country. As a result, students lost confidence in our own culture in the process of foreign language learning.

\section{Strategies for the construction of first- class foreign language subjects under the guidance of ideology and politics}

\subsection{Exploration of the ideological and political elements in foreign language teaching materials}

\subsubsection{Cultivation of students' worldview}

Textbook is a prerequisite for teaching, and the 
arrangement of the content of the textbooks establishes the benchmark for this course. Taking the textbook New Vision University English Reading and Writing Course as an example, teachers can strengthen the cultivation of students' worldview when teaching the relevant content of the third unit "Heroes of our time" in the first book. In our traditional cognition, the understanding of "hero" is a character who sacrifices himself for the people. Daniel, twenty years old, was facing a shooting peril and had the courage to sacrifice his life to protect others. And Dolly would rather give up his life and protect his wife. Among these narrations, the story of former South African President Nelson Mandela is obviously more resonant. This is closely related to the development of the times, and it also reminds teachers to choose examples in their daily life as much as possible when setting an example to students. Heroes have nothing to do with their origin, and they don't care about the return of their sacrifice. Society needs heroes. With the times continue to develop, there are also many obscure people who devote themselves to the society around us. They are the civilian heroes in our hearts. Students will have a deeper understanding of "heroes" and cultivate their correct worldview after studying this unit.

\subsubsection{Cultivation of students for morality}

In the textbook French Cultural Tour for Tour Guides, one of the themes of the second unit is "Integrity". We learned about the excellent traditional Chinese culture-honesty and trustworthiness in the text. Students can understand the manifestations and causes of dishonesty through the analysis and explanation of the article. Reading the harmful part of dishonesty will ring a bell in students and gradually guide students to think about how to solve this problem. As an effective supplement to the content of the text, we can make assignment that students use French to tell other social immoral phenomena and try to propose solutions. In addition, teachers can also accumulate them as writing materials and become the topic of writing training.

\subsection{Penetration of the concept of "Cultivation the virtue of people" in the construction of world-class foreign language majors}

Foreign language teachers are the main guides for students. In addition to creating a comfortable class for students, they should also pay attention to the combination of foreign language knowledge and ideological and political education which can allow students to actively participate in extracurricular practice that can be used as the main method for combining ideological and political content and foreign language knowledge. For example, students majoring in foreign languages can seize the opportunity of school cultural exchanges and be led by teachers to personally inspect English teaching abroad. Students use their foreign language knowledge to communicate with foreign students. At the same time, teachers can also focus on cultural protection issues, allowing students to strengthen the output of traditional Chinese culture, and scientifically absorb advanced foreign culture. On the other hand, teachers can also give full play to the advantages of information technology by use Massive Open Online Courses ( MOOC), Rain Classroom as virtual classrooms, guide students to read excellent books in foreign languages, and tell students about our country's traditional culture, find a fit, and let students learn While learning foreign languages, you can also absorb the essence of Chinese culture.

\subsection{Improvement of the ideological and political teaching ability of professional teachers}

In the teaching of foreign language, teachers need to strengthen their own political awareness, actively improve their ideological awareness, and broaden students' horizons based on the existing conditions and optimize teaching in the classroom. At the same time, having the goals of subject remain unchanged, it is necessary to make teachers collaborate more with ideological and political teachers, so that both parties can strengthen communication with each other and exchange the opinions of problems in the process of practice. That is how they can continuously improve foreign language and working ability. Ideology and politics courses are not simply the extension and closeness of those merely in the classroom, but intrinsically boost the morale of students. Foreign language teachers must have the ability to trigger profession-related social issues in order to achieve ideological and political education, and to improve students' self-cultivation and quality capabilities in learning and training.

\section{Conclusion}

To sum up, the ideological and political reform 
of foreign language courses is an inevitable trend to build first-class foreign language majors under the guidance of ideology and politics. It is also the basic requirement to realize the fundamental task of education and morality, and it is also the important practice of "Three Dimensional Education Concept" of higher education. Ideological and political education should run through the whole process of college students' education. It should not only be limited in the ideological and political education classroom. Instead, teachers should change the traditional ideological and political education concept, improve their own ideological and political education level, and put the ideology and politics courses into reality. Teachers should combine professional course teaching with ideological and political education, take moral education teaching into professional courses, and create a welcoming classroom. That said, students can better complete professional course learning under the guidance of correct ideological and political concepts.

\section{References}

[1] To firmly establish the "four consciousnesses" and strengthen the "four self-confidences", resolutely achieve the "two safeguards", be brave to take responsibility, and implement the decision-making and deployment of the Party Central Committee in a realistic and pragmatic style $[\mathrm{N}]$.

[2] Zhao XQ, Xiao F, Han YY. Investigation and analysis of the current situation of non-foreign language major graduate students' English needs under the background of "double first-class" construction: Taking 13 universities in Jiangsu as examples [J]. Foreign Language Studies. 2017.

[3] Li QD. A factor analysis of the lack of learning motivation of non-English major graduate students--Taking a "double firstclass" discipline construction university as an example [J]. College English Teaching and Research. 2019.

[4] Zu DQ, Yan J. Problems and measures for the development of English majors in science and engineering universities under the background of the "double first-class" strategy: Taking the construction of English majors in China University of Mining and Technology as an example [J]. Coal Higher Education. 2018. 